\title{
Antidepressant-Like Behavioral and Spatial Memory Effects in Peruvian Red Maca (Lepidium meyenii)-Treated Rats
}

\author{
Roberto O. Ybañez-Julca', Ivan M. Quispe-Díaz', Daniel Asunción-Alvarez', Kelly Sánchez-Muñoz', Albert \\ Vargas-Goñas', Jazminy Morote-Guzman ${ }^{1}$, Ronald Yaro-Marcelo ${ }^{1}$, Edmundo A. Venegas-Casanova ${ }^{1}$, Rafael \\ Jara-Aguilar', Pedro Buc Calderon ${ }^{2,3}$, Julio Benites ${ }^{1,2, *}$
}

Roberto O. Ybañez-Julca', Ivan M. Quispe-Díaz', Daniel AsunciónAlvarez' ${ }^{1}$, Kelly Sánchez-Muñoz ${ }^{1}$, Albert Vargas-Goñas ${ }^{1}$, Jazminy Morote-Guzman ${ }^{1}$, Ronald YaroMarcelo' ${ }^{1}$, Edmundo A. VenegasCasanova', Rafael Jara-Aguilar', Pedro Buc Calderon ${ }^{2,3}$, Julio Benites $^{1,2, *}$

${ }^{1}$ Facultad de Farmacia y Bioquímica. Universidad Nacional de Trujillo, Trujillo, PERU.

${ }^{2}$ Química y Farmacia, Facultad de Ciencias de la Salud, Universidad Arturo Prat, lquique, CHILE.

${ }^{3}$ Research Group in Metabolism and Nutrition, Louvain Drug Research Institute, Université catholique de Louvain, Brussels, BELGIUM.

\section{Correspondence}

\section{Julio Benites}

Facultad de Farmacia y Bioquímica. Universidad Nacional de Trujillo, Trujillo, PERU: Química y Farmacia, Facultad de Ciencias de la Salud, Universidad Arturo Prat, Iquique, CHILE.

Phone no.: +56 572416682

E-mail: juliob@unap.cl

\section{History}

- Submission Date: 08-10-2020;

- Review completed: 04-11-2020;

- Accepted Date: 11-11-2020.

DOI : 10.5530/pj.2021.13.12

Article Available online http://www.phcogj.com/v13/i1

\section{Copyright}

(C) 2021 Phcogi.Com. This is an openaccess article distributed under the terms of the Creative Commons Attribution 4.0 International license.

\section{ABSTRACT}

Introduction: Lepidium meyenii, known with the vernacular name of "Maca", is a Brassicaceae family that has been widely used by Peruvian traditional medicine in cases of sexual dysfunction, memory loss, and several other diseases and pathologies. Objetive: The aim of the study was to test the potential effects of aqueous extract of Red Maca (AQ-RM) on antidepressant-like behavioral in male rats and spatial memory in ovariectomized (OVX) rats. Methods: Forced swimming test was used to examine the potential antidepressant AQ-RM activity in male rats. Fluoxetine and amitryptiline were included as reference drugs. Morris Water Maze test was employed to examine the effect of AQ-RM on spatial memory in ovariectomized (OVX) rats. Such effects were compared to exogenous estradiol administration. The potential role of oxidative stress on spatial memory loss was assessed by measuring malondialdehyde (MDA) levels in rats brain homogenates. Results: AQ-RM enhances swimming and climbing activities while reducing the time of immobility in male rats. Meanwhile, it prevents the decrease in the time spent in the target quadrant and displays higher values in the number of crossings in OVX-rats as compared to OVX-control rats. MDA levels in brain homogenates were decreased in OVX-rats receiving AQ-RM. Conclusion: Oral administration of AQ-RM has anti-depressive application in male rats; and increases the ability of learning and memory in OVX rats.

Key words: Lepidium meyenii, Red Maca, Antidepressant activity, Forced swimming test, Spatial memory, Morris water maze test.

\section{INTRODUCTION}

Over the last two decades, the interest and demand for Lepidium meyenii, best known with the vernacular name of "Maca", have grown worldwide. This interest has established Maca as one of the flagship products of Peru, being sold as powder, pills, capsules, flour, liquor, and extracts at a variety of retail outlets such as health food stores and smoothie shops.

The Maca root, native to the Peruvian Andean region is botanically a member of the Brassicaceae family, growing in high altitude region, characterized by extreme weather conditions as rocky formations, intense sunlight and strong winds. ${ }^{2-6}$ There are diverse varieties according to the color of the hypocotyl, and many Maca root-based food supplements of different colors are available on the world market due to the possible effect on the treatment of a wide range of diseases and medical disorders. ${ }^{7}$ They include sexual dysfunction regulation, ${ }^{8}$ neuroprotective effects, ${ }^{9,10}$ memory enhancement, antidepressant, ${ }^{8,11}$ antioxidant, anticancer, and anti-inflammatory effects, ${ }^{12-14}$ and skin protection. ${ }^{15}$

In the Department of Junin (Carhuamayo), 13 varieties of Maca ranging from White to Black have been described. The most frequent was the Yellow color $(47.8 \%)$, the most preferred commercially; due to its properties to increase energy, improve attentiveness, and stabilize hormones. Red Maca accounts for about $25 \%$ of the annual harvest being the sweetest and highest in phytochemical levels among Maca powders with all litter colors. It is known as the most effective type for women because of its hormonal balance effects and its action on bone health. The Black Maca is the rarest of all colors, accounting for about 15\% of the annual harvest. Studies have shown that it is the most effective form for men, especially for muscle gain, endurance, brain focus, and libido.

It has been reported that Red Maca reduces rat benign prostatic hyperplasia induced by testosterone likely by stimulating androgen signally pathways ${ }^{16}$ and/or inhibiting TNF- $\alpha^{17}$ By looking other potential pharmacological properties, the aim of the present work was to study the effects of aqueous extract from Red Maca (AQ-RM) as antidepressant in a depression model in male rats and as enhancer of learning and memory in ovariectomized (OVX) rats.

\section{MATERIALS AND METHODS}

\section{Plant material}

The hypocotyls of Lepidium meyenii (Red Maca) were collected in September 2018 in the district of Carhuamayo, Province of Junin at $4000 \mathrm{~m}$ above sea level, in the Valle Mantaro, Peru. Once collected, the specimen was identified from the "Herbarium Truxillense de la Facultad de Ciencias Biológicas de 
la Universidad Nacional de Trujillo". A voucher sample was deposited in this herbarium.

\section{Lyophilized aqueous extract preparation}

The aqueous extracts of hypocotyls of Lepidium meyenii (Red Maca) were prepared as follows: $500 \mathrm{~g}$ of dried hypocotyls were weighted and pulverized, then added to $1.5 \mathrm{~L}$ of aqueous, and the mixture was subjected to reflux for 2 hours. The extraction process was repeated two times with another $1.5 \mathrm{~L}$ of aqueous. The extracts were mixed and filtered to remove insoluble particles and then evaporated under reduced pressure. The extract was frozen at $-80^{\circ} \mathrm{C}$ (Arctiko) and then lyophilized with a freeze-dryer (Labconco). The lyophilized was stored at $+4^{\circ} \mathrm{C}$ until analysis and further testing.

\section{Antidepressant activity}

\section{Animals}

Male Sprague-Dawley rats weighing between 150 and $200 \mathrm{~g}$ kept under controlled conditions (12-h dark/12-h light cycle, $23-25^{\circ} \mathrm{C}$, and $50-60 \%$ humidity) obtained from the animal house of the Instituto Nacional de Salud of Peru were used for the study. All experiments were conducted in accordance with international standards of animal welfare, and the experiments were performed in accordance with protocols approved by Ethics Committee for animal research of the Universidad Nacional de Trujillo (Res. Cons. Univ. No. 0361-2018/UNT). Groups of five animals were selected and, to reduce the influence of diurnal variation, all assays were conducted from 09:00 to 13:00 h. in a special noise-free room with controlled illumination. The animals received a standard food pellet, and before experiments, they were fasted overnight with water ad libitum.

The rats were randomly distributed into five experimental groups ( $\mathrm{n}=6$ per group). They were orally received: only vehicle (a); fluoxetine (FLX) at $10 \mathrm{mg} / \mathrm{kg}$ (b); amitriptyline (AMT) at $30 \mathrm{mg} / \mathrm{kg}$ (c); aqueous extract of Red Maca (AQ-RM) at $0.5 \mathrm{~g} / \mathrm{kg}(\mathrm{d})$; and $1.0 \mathrm{~g} / \mathrm{kg}$ of AQ-RM (e). The administration of vehicle or aqueous extract of Red Maca was during 28 days from 9:00 to 11:00 am.

\section{Forced swimming test (FST)}

The FST is the most widely used in vivo model for assessing pharmacological antidepressant activity. ${ }^{18,19}$ The development of immobility when the rats are placed in a cylinder filled with water, from which there is no escape, reflects the cessation of persistent escapedirected behavior. The apparatus consisted of a clear Plexiglas cylinder ( $40 \mathrm{~cm}$ high $\times 20 \mathrm{~cm}$ diameter) filled to $30 \mathrm{~cm}$ with water $\left(24 \pm 1^{\circ} \mathrm{C}\right)$. In the pre-test session, each animal was placed individually into the cylinder for $15 \mathrm{~min}, 24 \mathrm{~h}$ prior to the 5 min swimming test. AQ-RM, fluoxetine and amitriptyline were administered once day during 28 days prior to the swimming test. During the 5-min swimming test, the following behavioral responses were recorded: a) climbing (or thrashing), that means upward-directed movements of the forepaws along the side of the swim chamber; b) swimming, denoting movement through the swim chamber, which included crossing into another quadrant; and c) immobility, considered when the rat made no attempt to escape except the required movements to keep its head above the water. Increases in active responses, such as climbing or swimming, and reduction in immobility, are taken as behavioral profiles consistent with an antidepressant-like action. ${ }^{18}$

\section{Spatial memory}

\section{Animals}

Three-month-old female rats from the Sprague-Dawley strain obtained from the animal house of the Instituto Nacional de Salud of Peru were used for the study. Rats were housed 6 per cage and maintained at ambient temperature $\left(23-25^{\circ} \mathrm{C}\right)$ with a 12 -h dark/12-h light cycle in the animal house at the Universidad Nacional de Trujillo. The animals received a standard food pellet, and before experiments, they were fasted overnight with water ad libitum.

The rats were randomly distributed into five experimental groups $(n=6$ per group), as follows: a) Naïve, not ovariectomized rats (no OVX); b) OVX-rats; c) OVX-rats treated with $200 \mu \mathrm{g} / \mathrm{kg}$ estradiol valerate (EV); d) OVX-rats treated with $0.5 \mathrm{~g} / \mathrm{kg}$ AQ-RM; and e) OVX-rats treated with $2.0 \mathrm{~g} / \mathrm{kg} \mathrm{AQ-RM}$. Both naive and OVX-rats were administered $\mathrm{NaCl} 0.9 \%$ orally. The administration of vehicle or aqueous extract of Red Maca was during 28 days from 9:00 to 11:00 am.

\section{Ovariectomy}

Rats at the age of three months were anesthetized by intraperitoneal injection of $110 \mathrm{mg} / \mathrm{kg}$ of ketamine using standard procedures. ${ }^{20}$ Briefly, anesthesia was confirmed by reduced respiratory rate and absence of response to gentle pinching the footpad. A ventral incision was made through the skin on the right flank. In the OVX groups, the ovary, oviduct, and top of the fallopian tubes were clamped and removed. Skins and abdominal walls of animals of OVX groups were sutured, and animals were returned to their cages. Animals were included in the experiments two months after they were ovariectomized.

\section{Morris Water Maze (MWM) Test}

The MWM test was carried out using the black circle pool $(60 \mathrm{~cm}$ depth, and $150 \mathrm{~cm}$ diameter) that is filled half-way with water $\left(26 \pm 1{ }^{\circ} \mathrm{C}\right) .^{21,22}$ Briefly, the procedure included four consecutive days of training with another day for a probe test. In this experiment, three trials per day were performed for each rat starting at different release positions to find the location of a plexiglas platform (located one $\mathrm{cm}$ below the water level). Rats not finding the platform within $60 \mathrm{sec}$ of the acquisition phase are either placed on the platform or guided to it. During the training days (acquisition test), the time spent to find the platform (escape latency) was assessed and compared as behaviors between the groups. Probe test was done on the 5th day without the platform. The animal was placed in a new starting position in the maze, facing the pool wall, $180^{\circ}$ from the original position of the platform. The rat was allowed to swim for 60 seconds in a single trial, and the time in the target quadrant and the number of times it crossed that quadrant was recorded. ${ }^{22}$

\section{Malondialdehyde (MDA) measurements in brain}

MDA levels were quantified using a minor modification of the method published by Esterbauer \& Cheeseman. ${ }^{23}$ Briefly, the rat brain was excised and kept to $4^{\circ} \mathrm{C}$. It was further homogenized with $20 \mathrm{mM}$ of phosphate buffer ( $\mathrm{pH} 7.4$ ) containing $140 \mathrm{mM}$ of $\mathrm{KCl}$. The mixture was centrifuged at $3000 \mathrm{rpm}$ for $10 \mathrm{~min}$ at $4^{\circ} \mathrm{C}$ and the supernatant was incubated at $37^{\circ} \mathrm{C}$ in a water bath in dark for $60 \mathrm{~min}$. Proteins were precipitated by adding $20 \mu \mathrm{L}$ of trichloroacetic acid $(10 \%, \mathrm{v} / \mathrm{v})$ and further centrifugation at $1000 \mathrm{rpm}$ for $10 \mathrm{~min}$ at $4^{\circ} \mathrm{C}$. To one $\mathrm{mL}$ of the supernatant obtained it was added $2 \mathrm{~mL}$ of thiobarbituric acid $(0.7 \%$; $\mathrm{w} / \mathrm{v}$ ) and the mixture was incubated for $60 \mathrm{~min}$ at $90^{\circ} \mathrm{C}$. Next, $4.0 \mathrm{~mL}$ of $\mathrm{n}$-butanol/pyridine $(15: 1 ; \mathrm{v} / \mathrm{v})$ and $0.5 \mathrm{~mL}$ of distilled water were added. Then, the mixture was shaken and centrifuged for $10 \mathrm{~min}$ at $4^{\circ} \mathrm{C}$ at $1000 \mathrm{rpm}$. Finally, MDA levels were spectrometrically recorded at $532 \mathrm{~nm}$. The standard calibration curve was calculated by using 1,1,3,3-Tetraethoxypropane as reference and the results were expressed in $\mu \mathrm{mol} / \mathrm{g}$ tissue.

\section{Statistical analysis}

The results are present as means \pm SEM (standard error of the mean). All data were analyzed using one-way analysis of variance (ANOVA) with the Tukey post hoc test. A $p$-value $\leq 0.05$ was considered statistically significance. 


\section{RESULTS AND DISCUSSION}

\section{Antidepressant activity}

Depression is a common mental disorder, which has dramatically increased affecting more that 264 million people worldwide while the lack of an effective treatment is a permanent challenge for psychopharmacological research today. ${ }^{24,25}$ Nowadays, the search for novel pharmacotherapies against depressant activity from medicinal plants has significantly progressed as show by the large number of herbal medicines under current evaluation for their psychotherapeutic potential in a variety of animal models. ${ }^{24,25}$ These studies provide useful information for the development of novel therapeutic agents from medicinal plants to be used in antidepressant activity.

The forced swimming test (FST) was employed to assess the potential antidepressant effect by aqueous extract Red Maca (AQ-RM). The results were compared to those obtained by a selective serotonin reuptake inhibitor (fluoxetine at $10 \mathrm{mg} / \mathrm{kg}$ ), and a non-selective serotonin and norepinephrine reuptake inhibitor (amitriptyline at $30 \mathrm{mg} / \mathrm{kg}$ ). Figure 1 shows active responses, namely climbing, swimming and reduction of immobility, a behavior profile indicating an antidepressant effect.

The results show in the Figure 1A that AQ-RM $(0.5$ and $1.0 \mathrm{~g} / \mathrm{kg})$ and fluoxetine significantly increased the swimming when compared with the control-treated group. The amitriptyline was not different when compared with the control-treated group. The results also indicated a dose-dependent effect by AQ-RM. Zheng et al. ${ }^{26}$ discussed the increased of swimming would be directly related to the increase in the content of polysaccharides in the aqueous extract of Maca.

Figure 1B shows a slight but no statistically significant effect on climbing time, by AQ-RM as compared to control-treated group ( $5.5 \pm 1.1 \mathrm{sec})$, while fluoxetine and amitriptyline increased it by $18.17 \pm 2.8$ and $31.33 \pm$ $1.1 \mathrm{sec}$, respectively. Indeed, serotoninergic compounds like fluoxetine have been reported to influence swimming whereas amitriptyline and drugs with selective effects on noradrenergic transmission are affecting climbing. ${ }^{27}$ In this context, it was suggested that climbing implies the adrenergic neurotransmission, while swimming involves the serotonergic (5-HT) neurotransmission. ${ }^{28}$

As expected, the immobility time of rats was strongly reduced when they were administered with either fluoxetine or amitriptyline (Figure 1C). As compared to control-treated group $(32.0 \pm 0.6 \mathrm{sec}), \mathrm{AQ}-\mathrm{RM}$ reduced in a dose-dependent way the immobility time at $11.67 \pm 4.0 \mathrm{~s}$ and $3.17 \pm$ $1.2 \mathrm{~s}$, at doses of 0.5 and $1.0 \mathrm{~g} / \mathrm{kg}$ respectively. Meanwhile other studies have shown that petroleum ether extract from Maca (collected in Xizang, China) at doses of 250 and $500 \mathrm{mg} / \mathrm{kg}$, significantly decreased the duration of immobility in mice, indicating that Maca extract had antidepressant activity. ${ }^{29}$ Moreover, Rubio et al. ${ }^{11}$ reported that Yellow, Red and Black Maca reduced in similar extents the immobility time in OVX mice. Moreover, since quercetin displays antidepressant activity, ${ }^{30}$ it is tempting to suggest that the effect by Maca is likely due to the presence of phytoestrogens such as quercetin and anthocyanins.

\section{Spatial Memory}

Ovariectomy is a chirurgical procedure widely used to generate an in vivo condition mimicking post-menopausal pathophysiological changes in women associated with learning and memory. ${ }^{31}$ It is characterized by progressive memory deficits, central cholinergic nerve system degeneration, excessive oxidative stress and differentiation/apoptosis imbalance, ${ }^{32}$ brain oxidative stress ${ }^{33}$ and alteration of cholinergic and monoaminergic function. . $^{32,34}$

The Morris water maze is a well-established paradigm for evaluating deficits in hippocampal-dependent memory. In particular, learning and memory deficit is demonstrated by the extended time in acquisition and retention. The Morris water maze has been used to test spatial memory in many studies, for instance exogenous estrogen replacement improve spatial memory in ovariectomized rats. ${ }^{35}$

In the present study, ovariectomy resulted in impairment on memory function as observed in the water Morris maze test. These results are in accordance with those reported in previous studies. ${ }^{11,36}$ Although hormone deprivation due to ovariectomy causes spatial memory

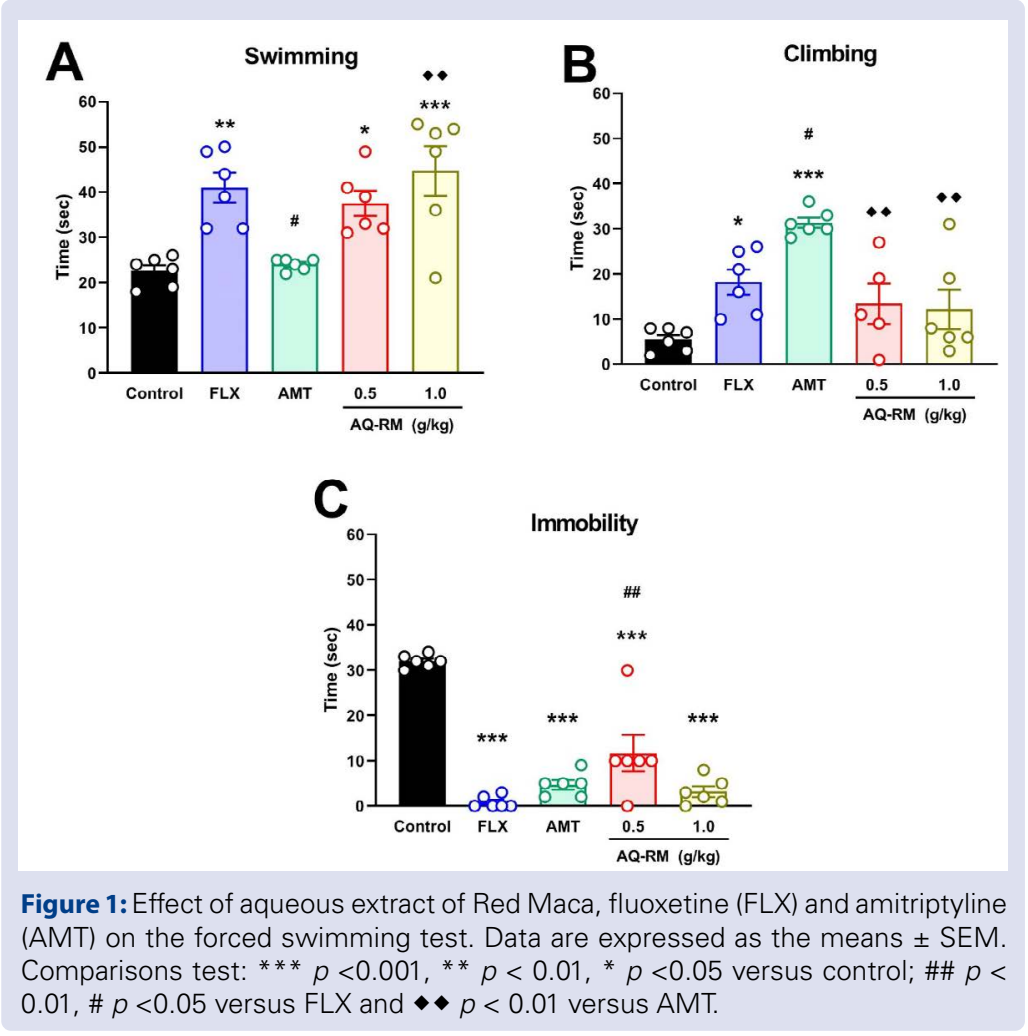


deficits, it is important to notice that estrous cycle may influence the performance in memory tests. ${ }^{37}$

Figure 2 shows that OVX rats showed lower time in the target quadrant and lower number of crossings than rats in naive group. Meanwhile, estrogen administration restores spatial memory to normal values (naive rats). The effects by AQ-RM were similar to that observed by estrogen in OVX-rats. Indeed, AQ-RM also restores, in a dosedependent manner, the time spent in the target quadrant $(19.67 \pm 0.6$ sec and $28.17 \pm 0.9 \mathrm{sec}$, respectively) as compared to OVX-rats Figure 2A. Meanwhile, AQ-RM, only at $2.0 \mathrm{~g} / \mathrm{kg}$, increased the number of crossings of the previous location of the platform when compared to OVX-rats (Figure 2B). These results clearly show that AQ-RM was able to alleviate the effect of ovariectomy. Since the water Morris maze is dealing with spatial learning and memory abilities, ${ }^{38}$ it may be concluded that AQ-RM improve spatial learning and memory deficits provoked by ovariectomy.

In addition to disturbances in both spatial learning and memory, ovariectomy of rats and surgical post-menopause increases ROS production via the mitochondrial respiratory chain and impaired antioxidant defense system. ${ }^{39}$ The human body has several mechanisms to counteract oxidative stress through the production of antioxidants. This production plays an important role in preventing or alleviating chronic diseases by reducing the oxidative damage to cellular components caused by reactive oxygen species. ${ }^{39}$ It should be stressed that brain is susceptible to be oxidized by free radicals.$^{40} \mathrm{Lipid}$ peroxidation (LPO) readily decomposes to liberate carbonyl fragments, the most prominent being MDA, which are highly reactive and responsible for cytotoxic effects and neuronal death. ${ }^{40}$ From this, MDA levels can be taken as an indicator for the state of LPO and a recognized indicator of oxidative stress. The reported abnormal alteration in MDA levels and its relation to memory impairment have been showed in previous studies. ${ }^{41}$

In this context, Figure 3 shows that MDA brain levels was enhanced in OVX rats when compared with naïve group. Exogenous estrogen replacement hidden such oxidative process as seen by the same MDA levels in both naïve and OVX-estradiol groups $(p>0.05)$. AQ-RM decreased, in a dose dependent way, the formation of MDA in OVXrats.

Our results confirmed the capacity of $\mathrm{AQ}-\mathrm{RM}$ to reduce oxidative stress, suggesting that improvement in learning and memory abilities in OVX-rats is likely due to its capacity to reduce oxidative stress.

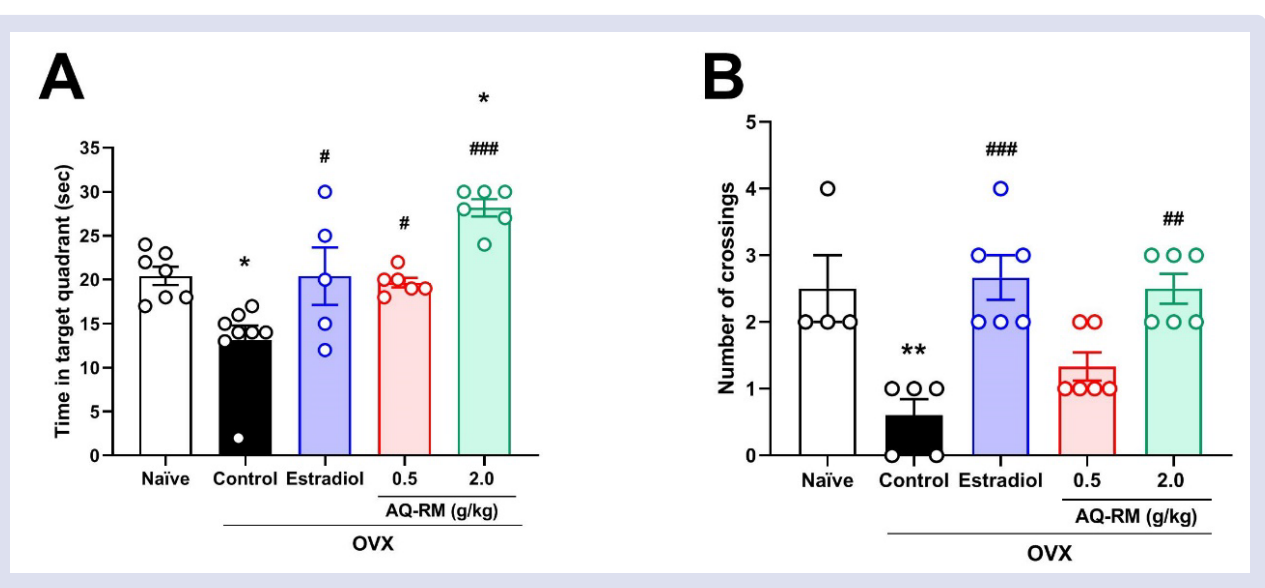

Figure 2: Effect of aqueous extract of Red Maca on (A) the time in the target quadrant (s) and (B) number of crossing in OVX rats in the Morris water maze during the spatial memory test. Data are expressed as the means \pm SEM. Comparisons test: ${ }^{* *} p<0.001,{ }^{* *} p<0.01,{ }^{*} p<0.05$ versus naive group and \#\#\# $p<0.001$, \#\# $p<0.01$, \# $p<0.05$ versus OVX-control.

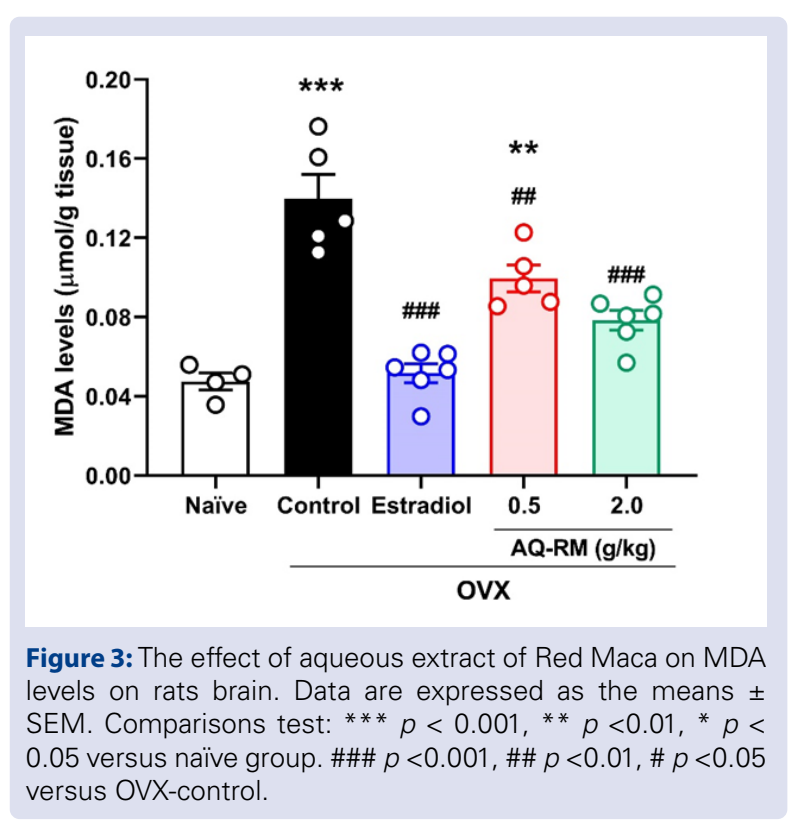




\section{CONCLUSION}

In summary, the results obtained after oral administration of aqueous extract of Red Maca in male rats demonstrated possible applications in CNS conditions, such as depression. It was further show that AQ-RM may enhance learning and memory in OVX rats. Additional studies are in progress in order to disclose its physiological mechanism, as well as its applicability as antidepressant-like and positive memory effects in behavioral disorders.

\section{CONFLICTS OF INTEREST}

The authors declare no conflicts of interest

\section{ACKNOWLEDGMENT}

The authors extend their appreciation to the VRI-UNT and the VRIIUNAP for financial support to this study.

\section{AUTHOR CONTRIBUTIONS}

ROYJ, IMQD, PBC and J.B. supervised the experimental work, and interpretation of the data, literature search, and wrote the manuscript. EAVC and RJA collected the plant species and carried out the preparation of extracts. DAA carried out the statistical analysis and the preparation of images. KSM and AEVG, performed the antidepressant assays. JIMG and RDYM performed ovariectomy and Spatial Memory experiments. All authors read and approved the final manuscript.

\section{REFERENCES}

1. da Silva NLP, Cabrera LPB, Medeiros LLM. Formigoni M, Fuchs RHB, Droval $A A$, et al. Medicinal effects of Peruvian maca (Lepidium meyeni): a review. Food Funct. 2020;11(1):83-92. https://doi.org/10.1039/c9fo02732g.

2. León J. The "Maca" (Lepidium meyenii), a little known food plant of Peru. Econ Bot. 1964;18(2):122-7. https://doi.org/10.1007/BF02862707.

3. Brinckmann J. Smith E. Maca culture of the Junín Plateau. J Altern Complement Med. 2004;10(3):426-30. https://doi.org/10.1089/1075553041323821.

4. Gonzales GF, Gonzales C, Gonzales-Castañeda C. Lepidium meyenii (Maca): a plant from the highlands of Peru-from tradition to Science. Forsch Komplementmed. 2009;16(6):373-80. https://doi.org/10.1159/000264618.

5. Valentová K, Frcek J, Ulrichová J. Yacon (Smallanthus sonchifolius) and Maca (Lepidium meyenii), traditional Andean crops as new functional foods on the European market. Chem Listy. 2001;95(10):594-901.

6. Wang Y, Wang, Y, McNeil B, Harvey LM. Maca: An Andean crop with multipharmacological functions. Food Res Int. 2007;40(7):783-792. https://doi. org/10.1016/j.foodres.2007.02.005.

7. Balick MJ, Lee R. Maca: from traditional food crop to energy and libido stimulant. Altern Ther Health Med. 2002;8(2):96-98. PMid:11890390.

8. Brooks NA, Wilcox G, Walker KZ, Ashton JF, Cox MB, Stojanovska L. Beneficial effects of Lepidium meyenii, (Maca) on psychological symptoms and measures of sexual dysfunction in postmenopausal women are not related to estrogen or androgen content. Menopause. 2008;15(6):1157-62. https://doi.org/10.1097/ gme.0b013e3181732953; PMid: 18784609.

9. Alquraini A, Waggas D, Böhlke M, Maher T, Pino-Figueroa A. Neuroprotective effects of Lepidium meyenii, (Maca) and macamides against amyloid-beta (2535) induced toxicity in B-35 neuroblastoma cells. FASEB J. 2014;28:657.13.

10. A. Pino-Figueroa, D. Nguyen and Maher TJ. Neuroprotective effects of Lepidium meyenii (Maca), Ann. N. Y. Acad. Sci. 2010, 1199, 77-85. https://doi.org/ 10.1111/j.1749-6632.2009.05174.x; PMid: 20633111.

11. Rubio J, Caldas M, Dávila S, Gasco M, Gonzales GF. Effect of three different cultivars of Lepidium meyenii (Maca) on learning and depression in ovariectomized mice. BMC Complement Altern Med. 2006;6(23):1-7. https:// doi.org/10.1186/1472-6882-6-23; PMid: 16796734.

12. Zheng W, Du S, Tian M, Xu W, Tian Y, LiT, et al. Lepidium meyenii Walp Exhibits Anti-Inflammatory Activity against ConA-Induced Acute Hepatitis. Mediators Inflamm. 2018;2018: 8982756. https://doi.org/10.1155/2018/8982756; PMid: 30647537.

13. Rodríguez-Huamán Á, Casimiro-Gonzales S, Chávez-Pérez JA, GonzalesArimborgo C, Cisneros-Fernández R, Aguilar-Mendoza LA, et al. Antioxidant and neuroprotector effect of Lepidium meyenii (maca) methanol leaf extract against 6-hydroxy dopamine (6-OHDA)-induced toxicity in PC12 cells. Toxicol Mech Methods. 2017; 27(4):279-285. https://doi.org/ 10.1080/15376516.2016.1275908; PMid: 28007001.
14. Bai N, He K, Roller M, Lai Ch-S, Bai L, Pan M-H. Flavonolignans and Other Constituents from Lepidium meyenii with Activities in Anti-inflammation and Human Cancer Cell Lines. J Agric Food Chem. 2015;63(9): 2458-63. https://doi. org/10.1021/acs.jafc.5b00219; PMid: 25667964.

15. Gonzales-Castañeda C, Gonzales, GF. Hypocotyls of Lepidium meyenii (maca), a plant of the Peruvian highlands, prevent ultraviolet A-, B-, and C-induced skin damage in rats. Photodermatol Photoimmunol Photomed. 2008;24(1):24-31. https://doi.org/10.1111/j.1600-0781.2008.00330.x; PMid: 18201354.

16. Cryan JF, Markou A, Lucki I. Assessing antidepressant activity in rodents: recent developments and future needs. Trends Pharmacol Sci. 2002;23(5):238 45. https://doi.org/10.1016/s0165-6147(02)02017-5; PMid:12008002.

17. Díaz $P$, Cardenas $H$, Orihuela PA. Red Maca (Lepidium meyenii) did not affect cell viability despite increased androgen receptor and prostate-specific antigen gene expression in the human prostate cancer cell line LNCaP. Andrologia. 2016;48(8):922-6. https://doi.org/10.1111/and.12681. PMID: 27681649.

18. Vásquez-Velásquez C, Gasco M, Fano-Sizgorich D, Gonzalez GF. Inflammatory pathway employed by Red Maca to treat induced benign prostatic hyperplasia in rats. Andrologia. 2020;52(3):e13516. https://doi.org/10.1111/and.13516; PMID:31989657.

19. Mora S, Díaz-Veliz G, Millan R, Lungenstrass H, Quirós S, Coto-Morales T et al. Anxiolytic and antidepressant-like effects of the hydroalcoholic extract from Aloysa polystachya in rats. Pharmacol Biochem Behav. 2005;82(2):373-78. https://doi.org/10.1016/j.pbb.2005.09.007.

20. Benites J, Asunción-Alvarez HD, Ybañez-Julca RO, Ganoza-Yupanqui ML, Jacinto-Fernadez, JJ, Reyes-De la Vega, JB, et al. Chemical composition by HPLC-ESI-OTOF-MS/MS: Estrogenic and antioxidants effects of Mangifera indica L. CV. "Kent" leave extracts on ovariectomized rats. Bol Latinoam Caribe Plantas Med Aromat. 2019;18(3):336-46

21. Nunez J. Morris water maze experiment. JVis Exp. 2008:19;897-98. https://doi. org/10.3791/897; PMid:19066539.

22. Vorhees ChV, Williams MT. Morris water maze: procedures for assessing spatial and related forms of learning and memory. Nat Protoc. 2006;1(2):84858. https://doi.org/10.1038/nprot.2006.116; PMid: PMC2895266.

23. Esterbauer H, Cheeseman K.H. Determination of aldehydic lipid peroxidation products: malonaldehyde and 4-hydroxynonenal. Methods Enzymol. 1990;186:407-21. https://doi.org/10.1016/0076-6879(90)86134-h; PMid:2233308.

24. Fathinezhad Z, Sewell RDE, Lorigooini Z, Rafieian-Kopaei M. Depression and Treatment with Effective Herbs. Curr Pharm Des. 2019;25(6):738-45. https:// doi.org/10.2174/1381612825666190402105803; PMid: 30947651.

25. Hao Y, Ge H, Sun M, Gao Y. Selecting an Appropriate Animal Model of Depression. Int J Mol Sci. 2019; 20(19):4827-43. https://doi.org/10.3390/ ijms20194827; PMid:31569393.

26. Zheng BL, He K, Hwang ZY, LuY, Yan SJ, Kim C, et al. Effect of Aqueous Extract from Lepidium meyenii on Mouse Behavior in Forced Swimming Test. Am Chem Soc. 2001;18:258-68. https://doi.org/10.1021/bk-2002-0803.ch018.

27. Cryan JF, Page ME, Lucki I. Differential behavioral effects of the antidepressants reboxetine, fluoxetine, and moclobemide in a modified forced swim test following chronic treatment. Psychopharmacology (Berl). 2005;182(3);335-44. https://doi.org/ 10.1007/s00213-005-0093-5; PMid:16001105.

28. Detke MJ, Rickels M, Lucki I. Active behaviors in the rat forced swimming test differentially produced by serotonergic and noradrenergic antidepressants. Psychopharmacology (Berl). 1995;121(1):66-72. https://doi.org/ 10.1007/ BF02245592; PMid:8539342.

29. Ai Z, Cheng A-F, Yu Y-T, Yu L-J, Jin W. Antidepressant-like behavioral, anatomical, and biochemical effects of petroleum ether extract from maca (Lepidium meyenii) in mice exposed to chronic unpredictable mild stress. J Med Food. 2014;17(5):535-42. https://doi.org/ 10.1089/jmf.2013.2950; PMid: 24730393.

30. Anjaneyulu M, Chopra K, Kaur I. Antidepressant activity of quercetin, a bioflavonoid, in streptozotocin-induced diabetic mice. J Med Food. 2003;6(4);39195. https://doi.org/10.1089/109662003772519976. PMid:14977450.

31. Sato T, Teramoto T, Tanaka K-I, Ohnishi Y, Irifune M., Nishikawa T. Effects of ovariectomy and calcium deficiency on learning and memory of eight-arm radial maze in middle aged female rats. Behav Brain Res. 2003;142(1-2);207-16. https://doi.org/ 10.1016/s0166-4328(03)00010-x; PMid:12798282.

32. Singh M, Meyer EM, Millard WJ, Simpkins JW. Ovarian steroid deprivation results in a reversible learning impairment and compromised cholinergic function in female Sprague-Dawley rats. Brain Res. 1994;644(2):305-12. https:// doi.org/ 10.1016/0006-8993(94)91694-2. PMid:8050041.

33. Monteiro SC, Matté C, Bavaresco CS, Netto CA, Wyse ATS. Vitamins E and $C$ pretreatment prevents ovariectomy-induced memory deficits in water maze. Neurobiol Learn Mem. 2005;84(3):192-9. https://doi.org/10.1016/j. nlm.2005.08.002; PMid:16169259. 
34. Holschneider DP, Kumazawa T, Chen K, Shih JC. Tissue-specific effects of estrogen on monoamine oxidase A and B in the rat. Life Sci. 1998;63(3):155-60. https://doi.org/10.1016/s0024-3205(98)00255-0; PMid: 9698044.

35. Markham JA, Pych JC, Juraska JM. Ovarian hormone replacement to aged ovariectomized female rats benefits acquisition of the Morris water maze. Horm Behav. 2002;42(3):284-93. https://doi.org/ 10.1006/hbeh.2002.1819. PMid:12460588.

36. Zhu JL, Yang GL, Huang Y-M. Effect of soybean isoflavone on the cognitive function in ovariectomized mice. Zhong Nan Da Xue Xue Bao Yi Xue Ban. 2004;29(1):81-83. PMid:16137014

37. Warren SG, Juraska JM. Sex differences and estropausal phase effects on water maze performance in aged rats. Neurobiol Learn Mem. 2000;74(3):22940. https://doi.org/10.1006/nlme.1999.3948; PMid:11031129.
38. D'Hooge R, De Deyn PP. Applications of the Morris water maze in the study of learning and memory. Brain Res Brain Res Rev. 2001;36(1):60-90. https://doi org/10.1016/s0165-0173(01)00067-4; PMid:11516773.

39. Dilek M, Nazıroğlu M, Baha Oral, H, Övey S, Küçükayaz M, Tamer Mungan $\mathrm{M}$ et al. Melatonin Modulates Hippocampus NMDA Receptors, Blood and Brain Oxidative Stress Levels in Ovariectomized Rats. J Membrane Biol. 2010;233:135-42. https://doi.org/10.1007/s00232-010-9233-x

40. MarkesberyWR. Oxidative stress hypothesis in Alzheimer's disease. Free Radic Biol Med 1997;23(1):134-47. https://doi.org/10.1016/s0891-5849(96)00629-6; PMid:9165306.

41. Lu J, Zheng Y-L, Luo L, Wu D-M, Sun D-X, Feng Y-J. Quercetin reverses $D$-galactose induced neurotoxicity in mouse brain. Behav Brain Res. 2006;171(2):251-60. https://doi.org/ 10.1016/j.bbr.2006.03.043. PMid:16707173.

\section{GRAPHICAL ABSTRACT}

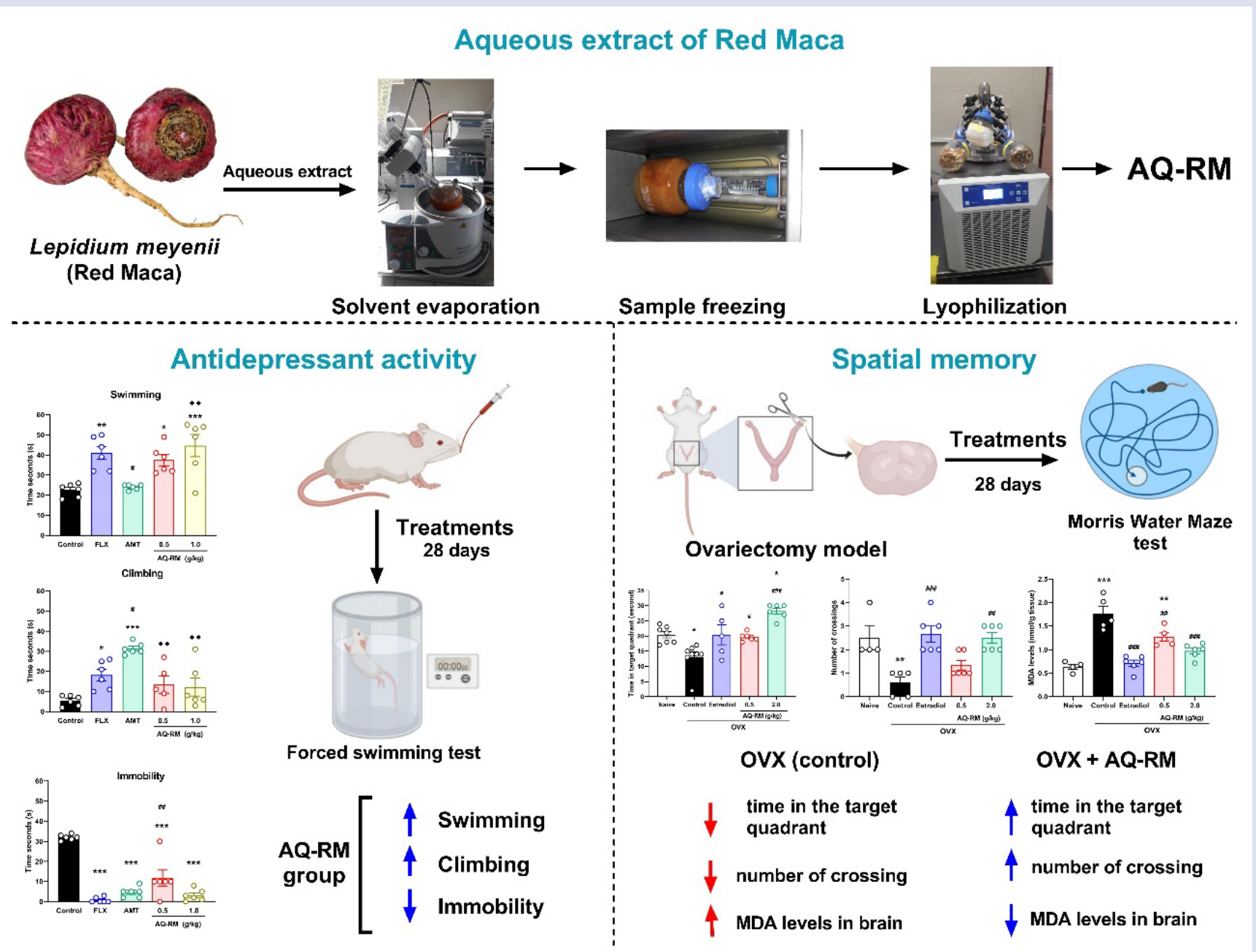

\section{ABOUT AUTHORS}

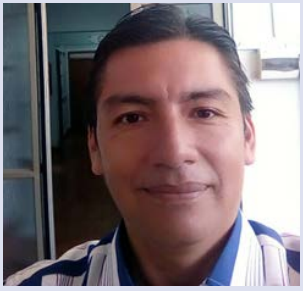

Dr. Roberto O. Ybañez-Julca. He is a Pharmaceutical Chemist. Doctor in Pharmacy and Biochemistry. Master in Clinical Pharmacy. Associate Professor, of the Academic Department of Pharmacology, Faculty of Pharmacy and Biochemistry, National University of Trujillo. Developing research in experimental pharmacology in mental health, antioxidants and hormone replacement therapy. 

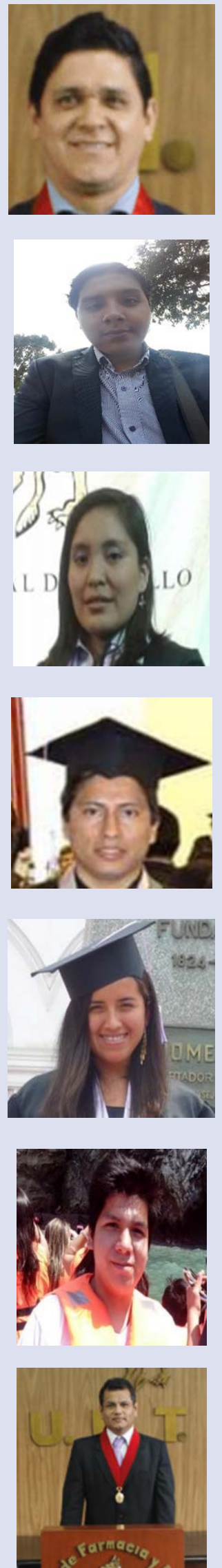

Dr. Ivan Quispe-Díaz. Professor of the Chair of Pharmacology and Pharmacotherapeutic of the Faculty of Pharmacy and Biochemistry of the National University of Trujillo, with a doctorate degree in Pharmacy and Biochemistry, master's degree in Public Health, bachelor's degree in Pharmacy and Biochemistry, Pharmaceutical Chemist. Developing research in experimental pharmacology in analgesia, antiinflammatories, depression, antispasmodics and uterotonics.

Daniel Asunción-Alvarez. Bachelor in Pharmacy and Biochemistry at the Universidad Nacional de Trujillo. Research assistant at Laboratory of Pharmacology. He has participated in projects on menopause, depression, memory impairment and their treatment and currently, in research projects on antioxidant, antispasmodic and spasmolytic activity of medicinal plants.

Kelly Sánchez-Muñoz. Pharmaceutical Chemist graduated from the National University of Trujillo, with experience in the pharmaceutical industry.

Albert Vargas-Goñas. Pharmaceutical Chemist graduated from the National University of Trujillo, with experience in the area of Health Establishment.

Jasminy Morote-Guzman. Pharmaceutical Chemist graduated from the National University of Trujillo, with experience in the area of Pharmaceutical Industry.

Ronald Yaro Marcelo. Pharmaceutical Chemist graduated from the National University of Trujillo, with experience in the area of Pharmaceutical Industry.

Dr. Edmundo A. Venegas Casanova. Pharmaceutical Chemist, Master in Therapeutic Natural Products, National University of Trujillo. Doctor in Pharmacy and Biochemistry, Auxiliary Professor D.E, of the Academic Department of Pharmacotechnology, Faculty of Pharmacy and Biochemistry, National University of Trujillo. Research line: protective effect of extracts, chemical composition of essential oil of plants medical as well as in the oxidation of vegetable oils. Research in therapeutic natural products. 

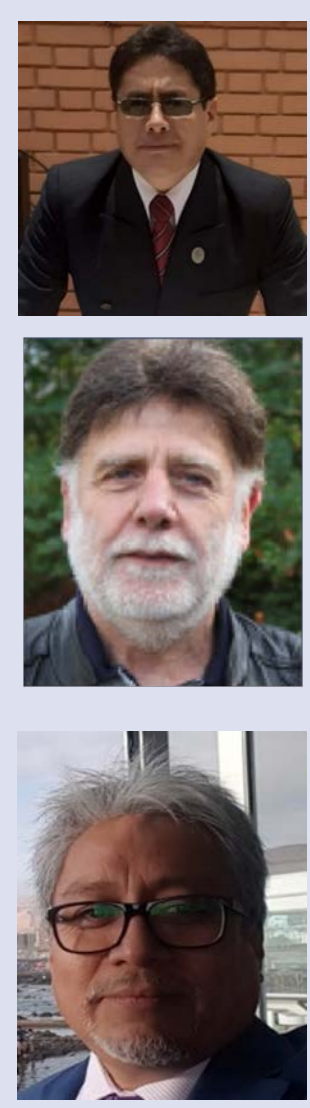

Dr. Rafael Jara-Aguilar. Pharmaceutical Chemist, Master in Chemical Sciences, National University of Trujillo. Doctor in Pharmacy and Biochemistry, Studies completed in the Specialty in Toxicology and Forensic Chemistry, Associate Professor D.E, of the Academic Department of Biochemistry, Faculty of Pharmacy and Biochemistry, National University of Trujillo. Research line: Physical chemical analysis of food, protective effect of extracts and essential oils of plants in the oxidation of vegetable oils, protein quality assessment by biological methods. Research in therapeutic natural products.

Dr. Pedro Buc Calderon. Pharmacist at the Universidad de Chile and Ph.D. in Pharmaceutical Sciences at the Université catholique de Louvain, Brussels, Belgium. He made research studies in Heidelberg (Germany), Brussels (Belgium) and Minnesota (United State). Dr. Buc is a Full Professor at the Department of Pharmaceutical Sciences; Faculty of Health Sciences, Arturo Prat University. He is vicechancellor for Research at the Arturo Prat University. He has research experience in the field of Natural Product of Chilean highlands as potential therapeutic agents against cancer.

Dr. Julio Benites. Pharmaceutical Chemist, Ph.D. of Chemistry from Pontifical Catholic University of Chile. He made postgraduate stays in Granada (Spain) and Lisbon (Portugal). Currently, Dr. Benites is Full Professor in the Department of Pharmaceutical Sciences of the Faculty of Health Sciences, Arturo Prat University. He is the Dean of Faculty of Health Sciences. He has experience in the area of Natural Product and Medicinal Chemistry in Natural and Synthetic Quinones as therapeutic agents.

Cite this article:Ybañez-Julca RO, Quispe-Díaz IM, Asunción-Alvarez D, Sánchez-Muñoz K, Vargas-Goñas A, Morote-Guzman J, et al. Antidepressant-Like Behavioral and Spatial Memory Effects in Peruvian Red Maca (Lepidium meyenii)-Treated Rats. Pharmacog J. $2021 ; 13(1): 81-8$. 